Mustafa Kemal Üniversitesi Sosyal Bilimler Enstitüsü Dergisi Mustafa Kemal University Journal of Social Sciences Institute Yıl/Year: 2018 Cilt/Volume: 15 Sayı/Issue: 41 s. 175-184

\title{
REGIME RELATED VOLATILITY IN OIL FUTURES PRICES
}

\author{
Ayben KOY \\ Istanbul Commerce University, Banking and Finance, akoy@ticaret.edu.tr \\ Orcid ID: 0000-0002-2506-6634 \\ Makale Geliş Tarihi: 15.12.2017 Makale Kabul Tarihi: 31.03.2018
}

\begin{abstract}
Oil futures prices, which have undergone major changes, maintain an important research topic for academics. Oil prices, which tended to decline for political and economic reasons in the 1990s, fell to as low as 12 US dollars after the Asian Crisis, rising again in 2002. The oil prices, which have fallen again after the 2008 crisis, have not reached the level of 100 US dollars again. This study explains the volatility of petroleum futures contracts as low and high volatility in two regimes by the Markov Regime Switching GARCH model. In the study based on 7077 observations in a long sample period from January 1990 to October 2017, the transition probabilities and durations between two different volatility regimes of oil futures prices are explained. The volatility of the oil futures contract is switching between two regimes with low volatility and high volatility depending on a markov process.

Keywords: MS GARCH, oil futures, volatility.

\section{VADELI PETROL FIYATLARINDA REJIMLE DEĞişEN VOLATILITE}

Öz

Büyük değişimler geçiren vadeli petrol fiyatları, akademisyenler için önemli bir araştırma konusu olmaya devam etmektedir. Politik ve ekonomik nedenlerle 1990'lı yıllarda düşme eğiliminde olan petrol fiyatları, Asya Krizi sonrası 12 ABD dolarına kadar düşmüş, 2002 itibariyle tekrar yükselmiştir. 2008 krizinden sonra tekrar düşme eğilimine giren petrol fiyatları, bir daha 100 ABD doları seviyesine ulaşmamıştır. Bu çalışma, Petrol vadeli işlem sözleşmelerinin volatilitesini düşük ve yüksek volatilite olarak iki rejimli bir Markov Rejim Değişim GARCH modeli ile açıklamaktadır. Ocak 1990-Ekim 2017 dönemindeki 7077 gözlemlik uzun bir örneklem dönemini ele alan çalışmada, iki farklı volatilite rejimi arasındaki geçiş olasılıkları ve durasyonları açıklanmıştır. Petrol vadeli işlem sözleşmesinin volatilitesi, düşük ve yüksek volatiliteye sahip iki rejim arasında bir markov sürecine bağı olarak geçiş yapmaktadır. Anahtar Kelimeler: MS GARCH, petrol vadeli işlem sözleşmeleri, volatilite.
\end{abstract}


Ayben KOY

\section{Introduction}

The global changes in oil prices have begun with the embargo of the 1970s and the oil prices in the 80s and 90s that followed the crisis in the range of $\$ 20-30$. Beginning from 1981 to 1987 the decline in oil demand due to the increase in oil production in non-member OPEC countries led to a barrel price declining by 8 dollars. Oil prices, which rose slightly in August 1990 when Iraq occupied Kuwait, showed a steady decline in the 1990s. After the Asian crisis of 1997, the prices declined to the level of 12 dollars, and the prices of Russia and OPEC have increased again due to the decrease of oil supply. Growth-related demand growth in the global economy after 2002 led to a rapid increase in oil prices. This upturn lasted until the 2008 crisis and the oil futures prices never reached to 100 dollars after July 2014. The big decline in 2015 were nearly 50\%. The oil futures prices have got an ongoing increasing outlook in last two years and fluctuates around 55 dollars in November 2017. Those major changes on oil futures prices, maintain the strength of being an important research topic for academicians. Secondary motivation of this research is volatility, which is a leading indicator of market risks followed by investors as much as market returns.

The volatility is expressed in terms of standard deviation and is calculated by taking the square root of the variance. The proposition that "the variances of the financial time series varies related to time" indicates that traditional time series models based on the assumption of constant variance are not sufficient. Firstly in 1982, Engle developed the autoregressive conditional variable variance model (ARCH) in order to estimate the time varying variance of financial assets. In the GARCH model developed by Bolerslev in 1986, Engle's ARCH model is generalized. The GARCH class models, which still maintain their popularity with the presentation of Engle and Bolerslev, are able to describe the features of the financial time series beyond the future volatility clusters, such as the extreme plausibility and thick tail.

In classical GARCH models, the variance of error terms is affected both by their own past values and by the values of their conditional variance. The GARCH models, which are often used and have been successful in modeling the variances in time series, have continued to be developed to test different features of the series.

The thresholded Generalized Autoregressive Conditional Variance (TGARCH) model developed by Zakoian (1994), GJRGARCH (Glosten, Jagannathan and Runkle, 1993), Integrated GARCH (IGARGH) (Nelson, 1990), Fractionally Integrated GARCH (FIEGARCH) (Baillie, Bolerslev and Mikkelsen, 1996), GARCH in mean (GARCH-M) (Engle, Lilien and Robins, 1987) are among the main linear GARCH models.

The exponential generalized autoregressive conditionally varying variance (EGARCH) model developed by Nelson (1991) is the first GARCH model to analyze a nonlinear relationship. Logistics smooth transition GARCH (LSTGARCH) (Hgerud, 1997 and Gonzalez-Rivera, 1998), Volatility switching GARCH (SGARCH) (Fornari and Mele, 1997), Asymmetric nonlinear smooth transition GARCH (ANST-GARCH) 
(Anderson, Nam and Vahid, 1999) and Quadratic GARCH (QGARCH) (Sentana, 1995), are the other nonlinear GARCH models.

The main structure of the Markov Regime Switching GARCH (MS GARCH) model, which is one of the Markov Regime Switching (MRS) models that analyze the financial markets in terms of the bear and bull markets used in our study, was created by Klaassen (1999). Kim (1993), Cai (1994), Hamilton and Sussel (1994) and Dueker (1997) are also the studies which have developed the constraints of the MS GARCH models.

Along with the development of commodity futures markets, contracts returns have also become a matter of academic work since Rockwell (1967). The statistical significance of returns (Grauer, 1977), hedging the portfolios with futures contracts (Bodie and Rozansky, 1980) and the systematic risk of futures contracts (Dusak, 1973; Grauer, 1977; Bodie and Rosansky, 1980) are some of the subjects in the early researches. According to Grauer and Litzenberger (1979), if future spot prices are uncertain, futures contracts (commodities) are risky assets. They also suggest that the equilibrium prices of futures contracts derive from uncertain relative and absolute commodity prices. The expected future spot price, which varies according to the actual social risk and the contractor's inflation appetite, constitutes the price of the commodity futures contract.

While there is no extensive literature on the nonlinear approach to modeling oil futures prices, the return and volatility of spot oil prices are analyzed using the nonlinear models in studies as Vo (2009), Kordnoori, Mostafaei and Ostadrahimi (2013) and Zlatcu, Kubinschi and Barnea (2015). Versus nonlinear models, there is a wide literature on modelling volatility of oil futures prices (Agnolucci, 2009; Sadorsky, 2006; Baum and Zerilli, 2016). Baum and Zerilli (2016) find significant evidence of jumps in returns using GMM stochastic volatility models and is a good base indicates the need of analyzing in a nonlinear approach.

Vo (2009) estimates the volatility of crude oil prices again with the Markov transitioned stock variability (MSSV) model. In another study, Zlatcu, Kubinschi and Barnea (2015) analyze the exchange response of international oil prices of retail fuel prices in Romania, Germany, France, Poland and Czech Republic with MTAR treshold cointegration tests after analyzing the volatility in oil prices with single and multivariable GARCH models. Kordnoori, Mostafaei and Ostadrahimi (2013), modeling fluctuations in spot oil prices, have integrated the limit probability distribution of a Markov chain and the Gumbel Max distribution.

Fong and See (2002) examined the volatility of daily returns in crude oil futures by the linear and nonlinear GARCH models. In the study that GARCH, Regime Switching (RS), RSARCH-t and RSGARCH-t models are used, regime switching models have been found useful in determining the variables behind volatility.

In the MRS approach, Chevallier (2013), uses Markov regime switching vector autoregressive model (MS VAR) to identify the effect of different economic variables 


\section{Ayben KOY}

on oil price oscillation. Zhang and Zhang (2015) selects three regimes and a secondorder Markov transition model (MS (3) -AR (2)) for the samples of crude oil prices before and after the 2008 financial crisis. In a similar research, Koy (2017) finds $\mathrm{MSIH}(3)-A R(0)$ model best describing oil futures prices for the period from January 2010 to December 2015. Finally, Günay (2016) is a good example using MS GARCH models for modelling volatility of oil returns which have got evidence that MS GARCH models with two regimes perform better than linear GARCH models.

\section{Data and Methodology}

The dataset, which started on January 02, 1990 and ended on October 31, 2017 , consists of a daily closing price of 7,077 US crude oil futures. Daily prices for the nearest futures contract are used. The stationary logarithmic differences of oil prices are studied which are gathered from Investing.com. Due to the difference process, the number of data used in the model is 7.076.

The West Texas Intermediate (WTI) Light Sweet Crude Oil Futures. It is equivalent to 1000 US barrels 42000 gallons of light, sweet crude oil. Brent, Middle East Sour Crude and WTI are the World's three most significant oil benchmarks. These contracts are quoted in dollars and cents per barrel.

\section{Markov Regime Switching GARCH Model}

In the MRS models, where the economy is not directly observable, the time series variable which is expressed as yt can be observed. The state of the economy so, can be obtained in probabilities. If the last state is known, estimating the following state $s_{1}$ is possible based on the probability of regime switching (Bildirici, Aykaç Alp, Ersin, Bozoklu, 2010). The MRS model has got a time series process (yt) dependent on an unobservable regime variable (st) (Krolzig, 2000):

$$
f\left(y_{t} / Y_{t-1} ; X_{t} ; \theta_{1}\right) \text { if } s_{t}=1
$$

$p\left(y_{t} / Y_{t-1} ; X_{t} ; s_{t}\right)=\left\{f\left(y_{t} / Y_{t-1} ; X_{t} ; \theta_{m}\right)\right.$ if $s_{t}=m$

Xt: exogenous variables; $\theta_{m}$ is the parameter vector associated with regime $m$.

In MRS models the regime-generating process is an ergodic Markov chain (Krolzig 2000).

$$
p_{i j}=\operatorname{Pr}\left(s_{t+1}=j / s_{t}=i\right) ; \sum_{j=1}^{m} P i j=1 ; i, j=\{1, . ., \mathrm{m}\}
$$

St follows an ergodic M-state Markov process with an irreducible transition matrix:

$$
\mathbf{P}=\left|\begin{array}{ccc}
p_{11} & \cdots & p_{1 m} \\
\cdots & \cdots & \cdots \\
p_{m 1} & \cdots & p_{m m}
\end{array}\right|
$$

The probabilities of transition from a state ( 1 or 2 ) to another state ( 1 or 2 ) in a two-state model are:

$P\left(s_{t+1}=1 \mid s_{t}=1\right)=p_{11}$

$P\left(s_{t+1}=2 \mid s_{t}=1\right)=p_{12}$, 


$$
\begin{aligned}
& \mathrm{P}\left(\mathrm{s}_{\mathrm{t}+1}=1 \mid \mathrm{s}_{\mathrm{t}}=2\right)=\mathrm{p}_{21}, \\
& \mathrm{P}\left(\mathrm{s}_{\mathrm{t}+1}=2 \mid \mathrm{s}_{\mathrm{t}}=2\right)=\mathrm{p}_{22} .
\end{aligned}
$$

MRS GARCH Model, has got a conditional mean, conditional variance, regime process and conditional distribution (Marcucci, 2005 and Günay, 2015).

$$
r_{\mathrm{t}}=\mu_{t}^{(i)}+\varepsilon_{t}=\delta^{(i)}+\varepsilon_{t}
$$

In the formula above, $\mathrm{i}=1,2, \varepsilon_{t}=\mathrm{n}_{\mathrm{t}} \sqrt{h_{t}}$ and $\eta_{\mathrm{t}}$ is the zero mean unit variance process. Knowing $h_{t-1}$ is the regime independent mean of the past conditional variance, the conditional variance of $\operatorname{GARCH}(1,1) r_{t}$ can be expressed as:

$$
h_{t}^{(i)}=\alpha_{0}^{(i)}+\alpha_{1}^{(i)} \varepsilon_{t-1}^{2}+\beta_{1}^{(i)} h_{t-1}
$$

\section{Empirical Results}

OXMetrics 7 program is used in the study. The statistics and ARCH test results of the logarithmic oil futures returns are given in Table 1. After calculating logarithmic differences the time series have become flattened. The hypothesis that the series have normal distribution is rejected. Another important result given in Table 1 is ARCH LM test result of model AR-MA(1,1). The hypothesis that the series do not have heteroskedasticity is rejected.

Table 1: The Statistics and ARCH Test

\begin{tabular}{llll}
\hline Statistics & Value & Statistics & Value \\
\hline Number of Observation & 7076 & Mean & -0.005320 \\
Standart Deviation & 0.979640 & Minimum & -4.0812 \\
Skewness & -0.020690 & Maximum & 3.3403 \\
Curtosis & -0.37647 & Median & 0.0050378
\end{tabular}

\footnotetext{
Asymptotic test: $\mathrm{Chi}^{\wedge} 2(2)=42.292[0.0000]^{* *}$

Normality test: $\mathrm{Chi}^{\wedge} 2(2)=47.976[0.0000]^{* *}$

ARCH 1-1 test: $F(1,7064)=14.697[0.0001]^{* *}$
}

As a result of the analysis with Oxmetrics 7, the two-regimed models have higher explanatory power than the linear models (LR linearity test: 2331.2), but no significant results are obtained in models with three or more regimes (Table 2). The two-regimed MS (2) GARCH model with 17845,6297 loglikelihood, -4.939409 akaike, $-4,929708$ schwarz (Table 2 ) indicates that oil futures volatility moves between the two regimes in which the market is located.

In other words, oil futures contracts have two different volatility models. The low / normal and high volatility periods demonstrated by these two models are shown as Regime 0 and Regime 1 . Oil futures prices switch between these two regimes depending on a Markov process. Oil remained at an average of 53.67 days at Regime 0 and 1.20 days at high volatile Regime 1 . If the last oil futures prices observed at Regime 0 , the next observation value will be at Regime 0 with $92 \%$ 


\section{Ayben KOY}

probability. Besides, the likelihood of the ongoing observation to switch to the regime 1 with high volatility is $8 \%$. On the other hand, if high volatility is observed, the next observation value will likely remain the same regime of $25 \%$, and switch to Regime 0 (75\%) (Table 4).

Table 2: MS (2) GARCH Information Criterions

\begin{tabular}{lllll}
\hline Model & $\begin{array}{l}\text { log- } \\
\text { likelihood }\end{array}$ & AIC & SIC & $\begin{array}{l}\text { LR } \\
\text { linearity test }\end{array}$ \\
\hline MS (2) GARCH & 17485.6297 & -4.939409 & -4.929708 & $\begin{array}{l}2331.2 \\
(0,000)\end{array}$ \\
\hline
\end{tabular}

Table 3: MS (2) GARCH Model Coefficients

\begin{tabular}{lll}
\hline & Coefficients & Standard Errors \\
\hline Coef. (0) & 0.001436 & 0.0002510 \\
Coef. (1) & -0.002187 & 0.001802 \\
Sigma (0) & 0.001436 & 0.000192 \\
Sigma (1) & 0.007977 & 0.003383 \\
alpha_1(0) & 0.037595 & 0.004197 \\
alpha_1(1) & 0.509467 & 0.241200 \\
beta_1(0) & 0.946360 & 0.005146 \\
beta_1(1) & 0.801220 & 0.099690 \\
p_\{0|0\} & 0.919469 & 0.023340 \\
p_\{1|1\} & 0.246470 & 0.123100 \\
\hline
\end{tabular}

Table 4: Switching Probabilities

Observed Regime

Switching Regime

\begin{tabular}{lll}
\hline & Regime 0 & Regime 1 \\
Regime 0 & 0.91947 & 0.080531 \\
Regime 1 & 0.75353 & 0.24647 \\
\hline
\end{tabular}

The gray vertical lines in Figure 1 represent the first regime in which high volatility is observed. It is notable that in the period of 1997-2001 the oil market switches to higher volatility regime at regular intervals and more frequently than in the other periods. Additionally, more than one regime switching take place between 2008-2010 and 2006.

The probability of occurrence of each regime in the sample period is shown in Figure 2. On the left, the probabilities of being in Regime 0 at any time is shown. On the right-hand side, the possibility of being in Regime 1 at any time in the period is depicted. The sum of the likelihood that the oil futures will be in Regime 0 or 
Regime 1 at any given time should be equal to 1 . Looking carefully at the figure, it seems to be compatible with this information. The prediction model illustrated in Figure 3 covers the 15 -day period from the last observation.

Figure 1: MS (2) GARCH Model

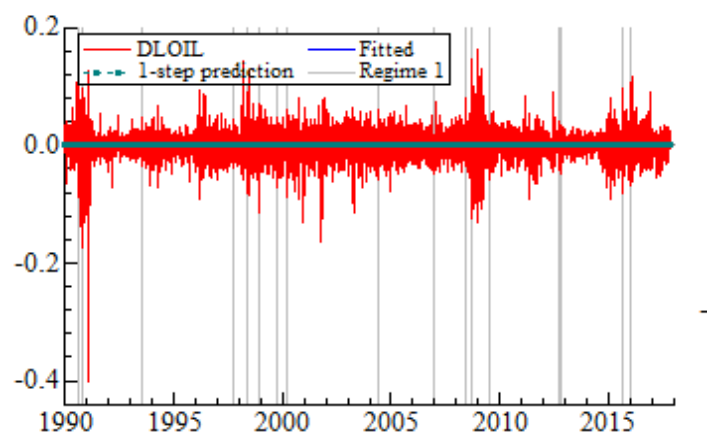

Figure 2: Switching Probabilities
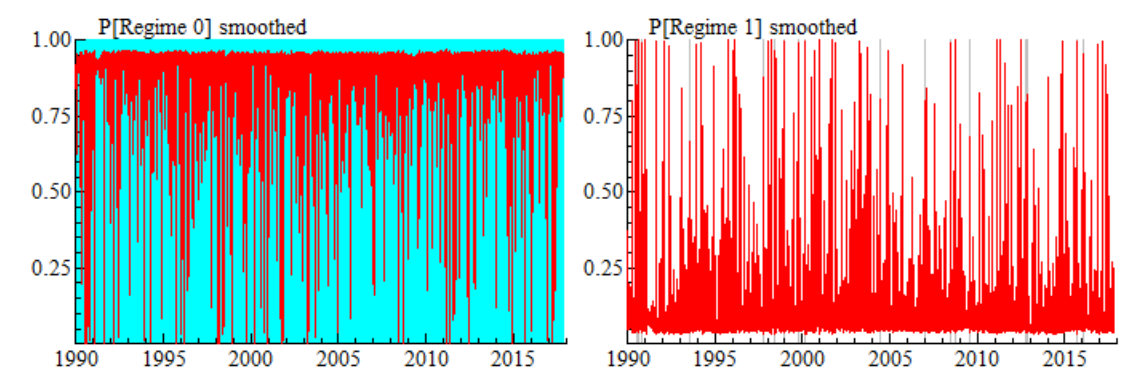
Ayben KOY

Figure 3: Estimation Model

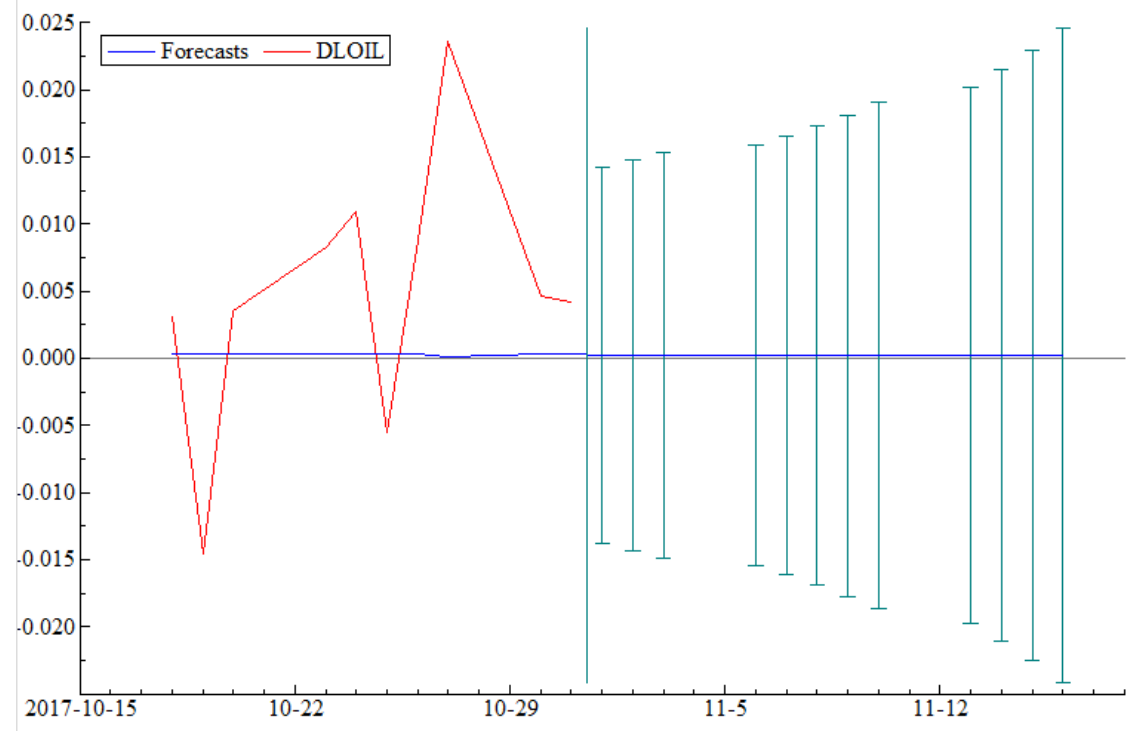

\section{Conclusion}

With the motivation of ongoing interest in oil futures prices and volatility, this research applies a nonlinear approach on WTI crude oil futures prices beginning from 1990 to 2017. The two regimed MS-GARCH model, which is one of the volatility models of MRS models, give us the evidence that oil futures volatility moves between the two different regimes. In other words, oil futures contracts have two different volatility models as the low / normal (regime 0 ) and high volatility (regime 1 ) periods. Besides, regime-spesific results of the models as the durations and probabilities give detailed information for investors of the oil futures market.

\section{References}

Agnolucci, P. (2009). Volatility in crude oil futures: A comparison of the predictive ability of GARCH and implied volatility models. Energy Economics, 31, 316321.

Anderson, H.M., K. Nam and Vahid, F. (1999). Asymmetric nonlinear smooth transition GARCH models. in P. Rothman (ed.), Nonlinear Time Series Analysis of Economic and Financial Data, Boston: Kluwer, 191-207.

Baillie, R.T., Bollerslevi T. and Mikkelsen, H.-O. (1996). Fractionally integrated generalized autoregressive conditional heteroskedasticity. Journal of Econometrics, 74, 3-30.

Baum, C. C. and Zerilli, P. (2016). Jumps and stochastic volatility in crude oil futures prices using conditional moments of integrated volatility. Energy Economics, $53,175-181$. 
Bildirici, M., Aykaç Alp, E.i Ersin, Ö. Ö. and Bozoklui Ü. (2010). Iktisatta Kullanılan Doğrusal Olmayan Zaman Serisi Yöntemleri. İstanbul, Türkmen Kitabevi.

Bodie, Z. and Rosansky V. I. (1980) Risk and Return in Commodity Futures. Financial Analysts Journal, 36(3) 27-39.

Cai, J., (1994). A Markov model of switching-regime ARCH. Journal of Business \& Economic Statistics, 12, 309-16.

Chevallier, J. (2013). Price relationships in crude oil futures: new evidence from CFTC disaggregated data. Environmental Economics and Policy Studies, 15(2), 133-170.

Dueker, M. J. (1997) Markov Switching in GARCH Processes and MeanReverting Stock Market Volatility. Journal of Business and Economic Studies, 15(1), 26-34.

Dusak, K. (1973). Futures Trading and Investor Returns: An Investigation of Commodity Market Risk Premiums. Journal of Political Economy, 81(6), 1387-1406.

Engle,R.F., Lilien, D. M. and Robins, R. P. (1987). Estimating time varying risk premia in the term structure: the ARCH-M model. Econometrica, 55, 391-407.

Fong, W. M. and See, K. H. (2002). A Markov switching model of the conditional volatility of crude oil futures prices. Energy Economics, 24(1):71-95.

Fornari, F. and A. Mele (1997). Sign and volatility switching ARCH models: theory and applications to international stock markets. Journal of Applied Econometrics, 12, 49-65.

Franses, P. H. and Dijk D. (2000). Nonlinear Time Series Models in Empirical Finance. Cambridge Universtiy Press.

Gonz'alez-Rivera, G., (1998). Smooth transition GARCH models. Studies in Nonlinear Dynamics and Econometrics, 3, 61-78

Glosten, L.R., R. Jagannathan and D.E. Runkle, (1993). On the relation between the expected value and the volatility of the nominal excess return on stocks. Journal of Finance, 48, 1779-801

Grauer, F. L. A. (1977). A Test of the Hypothesis that Backwardation is a Function of the Real Social Risk of Commodity Futures Contracts. Stanford University Graduate School of Business Dissertation. Chapter IV.

Grauer, F. L. A. and Litzenberger, R. H. (1979). The Pricing of Commodity Futures Contracts, Nominal Bonds and Other Risky Assets under Commodity Price Uncertainity. The Journal of Finance, 34(1), 69-83.

Günay, S. (2015). Markov Regime Switching Generalized Autoregressive Conditional Heteroskedastic Model and Volatility Modeling for Oil Returns. International Journal of Energy Economics and Policy, 5(4), 979-985.

Hagerud, G.E. (1997). A new non-linear GARCH model, PhD thesis, IFE, Stockholm School of Economic 
Ayben KOY

Hamilton, J.D. and Susmel, R. (1994). Autoregressive conditional heteroskedasticity and changes in regime. Journal of Econometrics, 64, 307-3.

Kim, C.-J. (1993=. Unobserved-components time series models with MarkovSwitching heteroskedasticity: changes in regime and the link between inflation rates and inflation uncertainty. Journal of Business \& Economic Statistics, 11, 341-9.

Klaassen, F. (1999). Improving GARCH volatility forecasts, Tilburg University, unpublished manuscript

Kordnoori, S., Mostafaei, H., and Ostadrahimi, M. (2013). Modelling the fluctuations of Brent oil prices by a probabilistic Markov chain. African Journal of Business Management, 7(17):1648-1654.

Krolzig, H- M. (2000). Predicting Markov-Switching Vector Autoregressive Processes. Mimeo, Institute of Economics and Statistics, University of Oxford.

Marcucci, J. (2005). Forecasting Stock Market Volatility with RegimeSwitching GARCH Models. Studies in Nonlinear Dynamics \& Econometricsi, 9(4), Retrieved 23 Nov. 2017, from doi:10.2202/1558-3708.1145.

Nelson, D. B. (1991). Conditional heteroskedasticity in asset returns: A new approach, Econometrica, 59(2), 347-370.

Nelson, D.B., (1990). Stationarity and persistence in the $\operatorname{GARCH}(1,1)$ model. Econometric Theoryi 6, 318-34

Roberti F. Eç (1982), Autoregressive Conditional Heteroskedasticity with Estimates of the Variance of United Kingdom Inflation. Econometrica, 50(4), 9871008.

Rockwell, C. S. (1967). Normal Backwardation, Forecasting and the Returns to Commodity Futures Traders. Food Research Institute Studies. 7, 107-130.

Sadorsky, P. (2006). Modeling and forecasting petroleum futures volatility. Energy Economics, 28, 467-488. 316-321

Sentana, E., (1995). Quadratic ARCH models. Review of Economic Studies, 639-61.

Vo, M. T. (2009). Regime-switching stochastic volatility: Evidence from the crude oil market. Energy Economics, 31(5):779-788.

Zakoikan, J. M. (1994). Threshold Heteroscedastic Models. Journal of Economic and Dynamic Control, 18(5), 931-955.

Zhang, Y.-J. and Zhang, L. (2015). Interpreting the crude oil price movements: Evidence from the Markov regime switching model. Applied Energy, 143(C):96-109.

Zlatcu, I., Kubinschi, M., and Barnea, D. (2015). Fuel Price Volatility and Asymmetric Transmission of Crude Oil Price Changes to Fuel Prices. Theoretical and Applied Economics, 22(4):33-44 